\title{
Webinar Menangkal Cyberporn Pada Internet dan Android Memanfaatan Add Ons dan Aplikasi Antipornografi Parental Control Di SMA Panca Budi
}

\author{
Supina Batubara', Sri Wahyuni ${ }^{2}$, Eko Hariyanto ${ }^{3}$, Akhyar Lubis ${ }^{4}$ \\ 1,2,3,4Universitas Pembangunan Panca Budi \\ email: 1supinabatubara@dosen.pancabudi.ac.id, 2sriwahyuni@dosen.pancabudi.ac.id, \\ 3eko.hariyanto@dosen.pancabudi.ac.id, ${ }^{3}$ akhyarlbs@pancabudi.ac.id
}

\begin{abstract}
Abstrak
Penyebaran konten pornografi melalui internet dan telepon seluler sudah sangat mengkawatirkan Pornografi di internet memang telah menjadi sebab industri dengan skala bisnis yang besar. Hingga saat ini pemerintah terlihat kesulitan untuk mengatasi persoalan situs pornografi. Upaya pemblokiran situs-situs pornografi di Indonesia terus dilakukan, namun, situs-situs porno (cyberporn) juga terus tumbuh. Dampak negatif cyberporn telah terbukti sangat mengkawatirkan terutama bagi remaja sebagai generasi muda. Dilakukan survey di Indonesia menunjukkan hasil responden 90 persen dari pelajar SD, SMP, dan SMA sudah mengakses pornografi. Orang tua memiliki tugas untuk melakukan pengawasan atau pengendalian (parental control) dari penggunaan internet bagi anaknya, terlebih lagi saat masa pandemi saat ini penggunaan internet pada perangkat android sudah menjadi kebutuhan primer. Untuk itu kegiatan pengabdian kepada masyarakat ini dilakukan dengan melaksanakan webinar yang dilengkapi dengan diskusi dan tanya jawab langsung oleh narasumber dengan tujuan agar orang tua dan pihak sekolah dapat mengetahu dampak negative paparan pornografi dan mengetahui cara memberantas bagaimana cara memblokir, menangkal, juga membasmi cyberporn di internet dan android. Hasil pelaksanaan webinar tim pengabdian dapat merangkum bahwa orang tua, guru dan pihak sekolah mampu melakukan penangkalan cyberporn sesuai dengan hasil yang diharapkan hal ini terlihat pada post-test setelah kegiatan webinar.
\end{abstract}

Kata Kunci: konten pornografi, internet, android, parental control

\begin{abstract}
The spread of pornographic content via the internet and cell phones is very worrying. Pornography on the internet has indeed become the cause of an industry with a large business scale. Until now, the government has seen difficulties in overcoming the problem of pornographic sites. Efforts to block pornographic sites in Indonesia continue, however, pornographic sites (cyberporn) also continue to grow. The negative impact of cyberporn has proven to be very worrying, especially for adolescents as the younger generation. A survey conducted in Indonesia showed that 90 percent of elementary, junior high and high school students have accessed pornography. Parents have a duty to supervise or control (parental
\end{abstract}


control) of internet use for children, especially during the pandemic, when the use of the internet on Android devices has become a primary need. This community service activity is carried out by conducting webinars that are equipped with discussions and direct questions and answers by the speakers with the aim that parents and schools can find out about the negative effects of exposure to pornography and monitor how members eradicate how to monitor, counteract, and eradicate cyberporn on the internet and android. The results of the implementation of the service team webinar can summarize that parents, teachers and schools are able to prevent cyberporn in accordance with the expected results, this can be seen in the post-test after the webinar activity.

Keywords: pornographic content, internet, android, parental control

\section{Pendahuluan}

Kemunculan internet menjadi cara termudah dalam mendistribusikan cyberporn. (Sudrajat, 2010) Pemerintah telah berushaa keras untuk memblokir dan mebasmi konten pornografi dengan membuat peraturan yang mengatur tentang pembuatan, pendistribusian, hingga kepemilikan cyberporn (Santoso, 2017) namun cyberporn tetap tumbuh, pepatah mengatakan mati satu tumbuh seribu (Bunga, 2011) Internet telah mejadi media sarana berbagi konten pornografi yang mudah dan bebas diakses siapapun bagi pengguna internet (Anwar, 2018) dampak negatif cyber-porn telah terbukti sangat mengkhwatirkan terutama bagi generasi muda dan anak-anak (Utomo, 2018) Pelecehan seksual yang sering terjadi dinegri kita merupakan bukti nyata bentuk pelarian akibat seringnya menkonsumsi konten pornografi (Diana, 2018) Pada pemenlitian yang telah dilakukan oleh (Owens et al., 2012) mengatakan bahwa cyberporn muncul pada peringkat 21, 26, dan 37 yang menunjukkan tingginya cyberporn oleh pengguna internet di Indonesia (Hasanah et al., 2017) Penelitian tentang dampak negatif dari cyberporn yang dihubungkan dengan perilaku seksual sangat beresiko hingga saat ini masih belum dapat disimpulkan (Sinković et al., 2013) Namun penelitian yang ada secara konsisten menunjukkan hubungan antara dampak cyberporn dengan berbau kekerasan dan perilaku seksual yang agresif (Hodson et al., 2013) Pihak yang terdekat dengan anak adalah orang tua. Tingginya akses anak terhadap konten internet yang negatif menunjukkan rendahnya pengawasan atau pengendalian orang tua terhadap akses internet yang dilakukan oleh anaknya (Maisyaa \& Masitoh, 2019) Oleh karena itu orang tua harus dibekali dengan pengetahuan dan literasi yang tinggi terhadap penggunaan internet (Rachmaniar et al., 2018) Saat ini dengan memanfaatkan add ons yang tersedia pada browser dan diperlukan aplikasi yang dapat membantu orang tua dalam mengontrol dan membatasi anak mengakses konten pornografi (Yati \& Aini, 2018) Webinar Menangkal Cyberporn Pemanfaatan Add Ons Dan Aplikasi Antipornografi Parental Control Di SMA Panca Budi (Hariyani et al., 2012) kegiatan pengabdian masyarakat bertujuan meningkatkan pengetahuan dan kesadaran orang tua tentang pentingnya parenting control terhadap akses internet yang dilakukan oleh anaknya, dan keterampilan yang meningkat dengan memanfaatkan add ons dan parental control aplikasi berbasis android yang dapat diterapkan dalam mengawasi akses internet 
yang dilakukan oleh anaknya. Berdasarkan analisis situasi di atas dapat diidentifikasi beberapa yaitu;

1) Kemungkinan akses konten pornografi yang tinggi dilakukan oleh siswa SMA Panca Budi saat mengakses internet disekolah

2) Pemahaman orang tua, guru dan pihak sekolah SMA Panca Budi yang kurang terhadap kebermanfaatan pengawasan anak saat mengakses internet

3) Orang tua, guru dan pihak sekolah SMA Panca Budi yang masih kurang memahami penggunaan gadget secara maksimal dengan cara aman

4) Orang tua, guru dan pihak sekolah SMA Panca Budi yang belum memahami cara penggunaan add ons dan aplikasi parental control

Berdasarkan masalah diatas dapat dirumuskan permasalahan sebagai berikut

1. Bagaimana kesadaran dan pengetahuan orang tua dapat meningkat dalam memahami pentingnya aplikasi parental kontrol terhadap penggunaan internet oleh anak

2. Bagaimana menentukan aplikasi yang cocok dan mudah digunakan oleh orang tua.

3. Bagaimana cara melatih orang tua dalam memanfaatkan add ons dan parental kontrol aplikasi berbasis andorid bagi orang tua

\section{Metode}

Dalam pelaksanaan Pengabdian Kepada Masyarakat terdapat beberapa subtansi pengetahuan dan teknologi yang dapat diberikan kepada masyarakat yaitu subtansi tentang pentingnya aplikasi parental kontrol dan memanfaatkan add ons dan menggunakan aplikasi parental control di android Kegiatan PKMS dikemas dalam sebuah Webinar Menangkal Cyberporn dengan Pemanfaatan Add Ons Dan Aplikasi Antipornografi Parental Control Di SMA Panca Budi.

Proteksi Pada Browser

Membahas Teknik memproteksi browser dari pornografi. Browser merupakan sebuah aplikasi yang digunakan untuk mengakses internet dan dari browser inilah konten pornografi ditampilkan. Add Ons adalah pemblokir situs porno yang telah terinstal di browser yang mampu memproteksi dan menghadang situs-situs yang mengandung unsur ponografi yang dikawatirkan yang akan dilihat oleh anak. Sebagaimana pemanfaatan dan penggunaan internet sehat telah disosialisasikan pada kegiatan pengabdian masyarakat (Hariyanto \& Wahyuni, 2020)

Karakteristik dan subtansi atau konten yang disampaikan kepada masyarakat peserta webinar. Tim Pengabdian menrangkum kegiatan akbar dalam dalam Webinar Menangkal Cyberporn Pemanfaatan Add Ons Dan Aplikasi Antipornografi Parental Kontrol Di SMA Panca Budi yang dilaksanakan pada tanggal 5 September 2020 Pukul $09.00 \mathrm{Wib}$ s/d $12.00 \mathrm{Wib}$. Weibinar dihadiri lebih dari 50 peserta yang hadir secara langsung dilokasi dan Sebanyak 416 Peserta Webinar yang menyaksikan secara online di youtube dan meeting zoom. Dalam pelaksanaan nya materi 
disampaikan oleh tim pengabdian yang dibagi pada 2 pembahasan utama dilakukan dengan metode ceramah dan diskusi langsung antara narasumber dan peserta webinar. Materi yang disampaikan yaitu:

1. Proteksi pada browser yang disampaikan oleh Supina Batubara, S,Kom., M.Kom dan Eko Hariyanto, S.Kom., M.Kom. Materi dikemas secara singkat padat dan jelas yaitu membahas add ons mozillafox filter dan Tiny Web Filter: Anti-Porn For Chrome

2. Penggunaan aplikasi antipornografi parental control

Aplikasi Parental Kontroladalah aplikasi yang terdapat pada televisi digital, video games, komputer dan perangkat mobile. ada 4 pembagian kategori yang disediakan oleh aplikasi parental kontrol yaitu;

a. konten filter: yang berfungsi untuk membatasi perangkat pengguna untuk menerapkan waktu penggunaan perangkat dan membatasi penggunaan aplikasi tertentu.

b. Pengawasan berfungsi untuk melacak keberadaan aktvitas perangkat

c. Menejemen perangkat pengguna komputer yang berfungsi hampir sama dengan pengawasan yaitu melacak lokasi dari aktivitas pengguna

d. Sistem parental kontrol yaitu berfungsi sebagai pengembangan baik sebagai keperluan dalam membatasi akses sistus dan aplikasi tertentu dengan sistem yang sudah dikembangkan kearah perangkat mobile.

Fungsi Parental Control

1) Untuk filtering, menyeleksi situs yang sehat dan aman. Membuat daftar hitam, artinya semua situs bisa dibuka, hanya beberapa situs saja yang kita masukkan tidak akan bisa dibuka. Sedangkan white list artinya tidak ada situs yang bisa dibuka kecuali beberapa situs saja yang sudah diprogram Misalnya, situs Disney atau pendidikan.

2) Pemantauan yang berfungsi agar orang tua dapat merekam aktivitas online anak. Misalnya, e-mail, situs yang dibuka.

3) Penjadwalan. anak dapat akses online pada waktu yang sudah ditentukan.

\section{Pelaksanan Kegiatan}

Sebelum kegiatan berlangsung tim pengabdian melakukan beberapa identifikasi yaitu;

1. Identifikasi kompetensi standar, indikator hasil webinar

a. Pentingnya memahami pengawasan kepada anak dalam penggunaan internet terutama pada akses pornografi

b. Mengenal aplikasi parental kontrol yang digunakan orang tua sebagai media pengawasan penggunaan internet bagi anak

c. Orang tua mampu memanfaatkan add ons dan mampu menggunakan aplikasi net nanny berfungsi sebagai parental control guna mengawasi anak terhadap akses konten pornografi 
Kompetensi yang dicapai yaitu:

1. Pengawasan kepada keluarga

2. Dampak negative pornografi

3. Fungsi dan Penggunaan Internet secara Efektif

4. Dampak negative penggunaan internet dengan tanpa pengawasan

5. Mengenal beberapa aplikasi parental kontrol

6. Memanfaatkan dan Mengimplementasikan aplikasi parental kontrol Indikator keberhasian webinar ini yaitu:

1. Mampu menjelaskan pentingnya pengawasan kepada keluarga terhadap penggunaan internet

2. Mengetahui dampak paparan pornografi

3. Memahami penggunaa internet secara efektif

4. Mampu menjelaskan bahaya akses internet dengan tanpa pengawasan

5. Mengenal aplikasi parental kontrol

6. Mempu menggunakan aplikasi parental kontrol

2. Identifikasi materi Parental Control Webinar Menangkal Cyberporn Pemanfaatan Add Ons Dan Aplikasi Antipornografi Parental Control Di SMA Panca Budi. Berdasarkan konsep Webinar yang disusun, materi yang dibutuhkan untuk disampaikan kepada peserta webinar dengan metode ceramah dan diskusi langsung antara nasumber dan peserta webinar baik luring maupun daring

Kegiatan PKMS yang dikemas dalam Webinar Menangkal Cyberporn Pemanfaatan Add Ons Dan Aplikasi Antipornografi Parental Control Di SMA Panca Budi juga dibantu oleh beberapa mahasiswa, vendor dan pihak terkait. Materi disampaikan oleh Akhyar, S.Kom., M.Kom dan Sri Wahyuni, S.Kom., M.Kom. Materi berisi penjelasan secara rinci tentang aplikasi parental control yang dapat memfalisitasi orang tua melakukan kontrol dan pengendalian terhadap penggunaan internet oleh anak. Salah satu aplikasi parental control yang dilatih kepada orang tua adalah Net Nanny dimaan fitur yang disediakan oleh Net Nanny sangat lengkap yaitu:

a) Memblokir akses websiteURL yang teridentifikasi pornografi, shooping online, gambling dan lain lain

b) Membantu orang tua memenejemen waktu akses internet bagi anak

c) Memberikan laporan tentang website yang sudah dikunjungi dan riwayat pencarian oleh anak

d) Melaporkan melalui email dan teks pesan dengan segera jika ditemukan akses link website yang sudah diblokir, termasuk juga usaha yang dilakukan untuk memasuki akses link URL yang telah di blokir

e) Manajemen program untuk anak yang usia berbeda 
f) Melacak penggunaan internet setiap anak di beberapa computer

g) Menelusuri riwayat online dan mengawasi anak dengan siapa saja dapat chatting

h) Mengontrol permainan yang dapat diakses oleh anak dengan memberikan keyakinan bahwa game yan dapat diakses disesuaikan dengan umur

i) Menejemen remote kontrol dengan memberikan detail laporan melalui email sebagai pemberitahuan jika ada akses yang dilanggar

\section{Hasil Kegiatan}

Berdasarkan pelaksanaan "Webinar Menangkal Cyberporn Pemanfaatan Add Ons Dan Aplikasi Antipornografi Parental Control Di SMA Panca Budi" dilaksanakan tanggal 05 September 2020, Tim pengabdian melakukan pre-test pada saat sebelum webinar dilaksanakan dan melakukan post-test juga menyebar kuisioner setelah pelaksanaan kegiatan webinar. Beberapa kompetensi yang dimiliki orang tua, guru dan pihak sekolah yaitu;

1. mampu memahami dampak pengawasan penggunaan internet kepada keluarga

2. mengetahui dampak negative terpapar pornografi

3. menggunakan internet sevara efetif dan sehat

4. mampu menjelaskan bahaya akses internet tanpa pengawasan

5. Mengenal aplikasi parental kontrol

6. Peserta dapat menggunakan net nanny sebagai aplikasi parental control

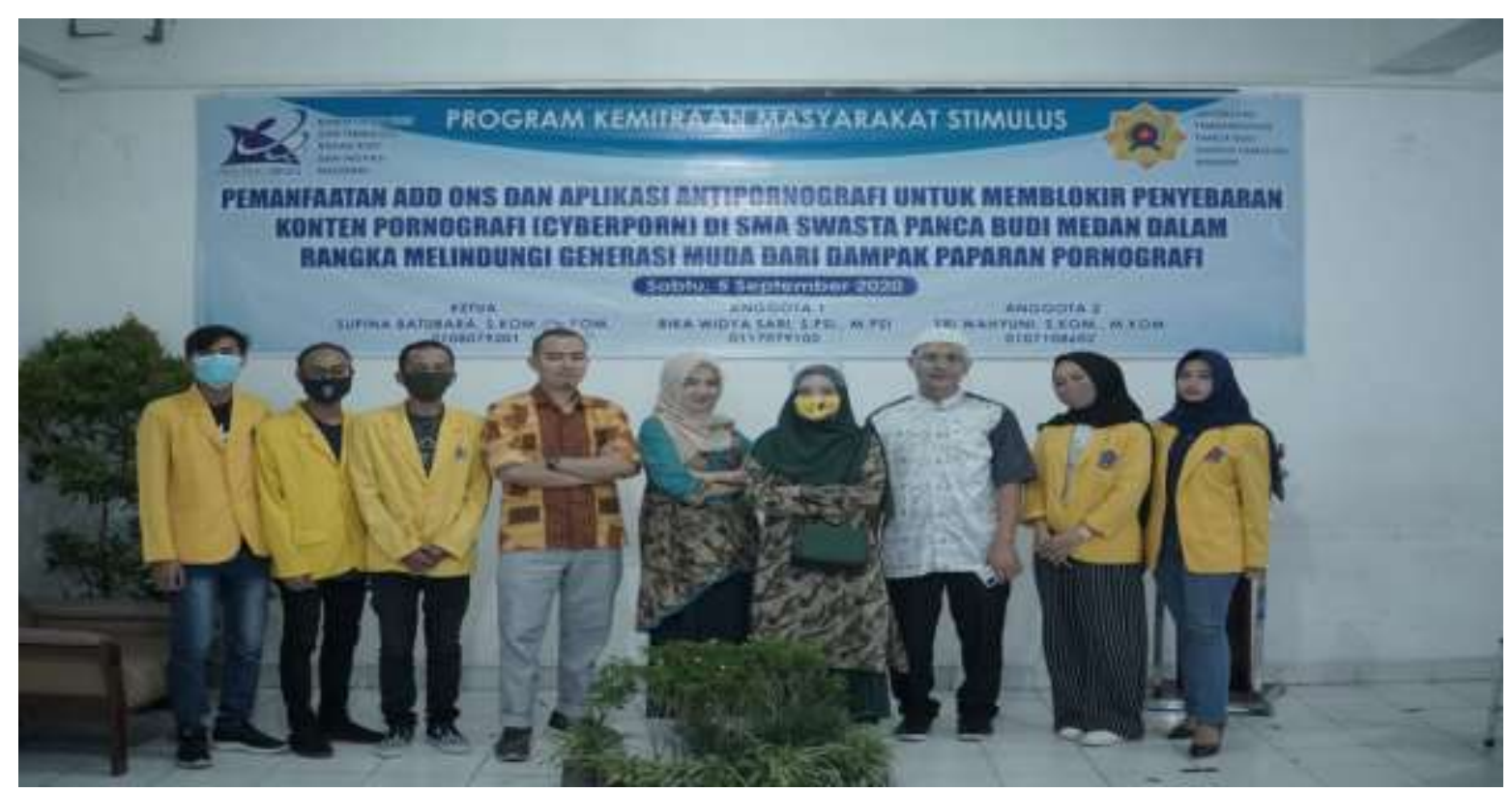

Gambar 1. Photo Bersama TIM PKMS 


\section{JURNAL ABDIMAS BSI}

Jurnal Pengabdian Kepada Masyarakat

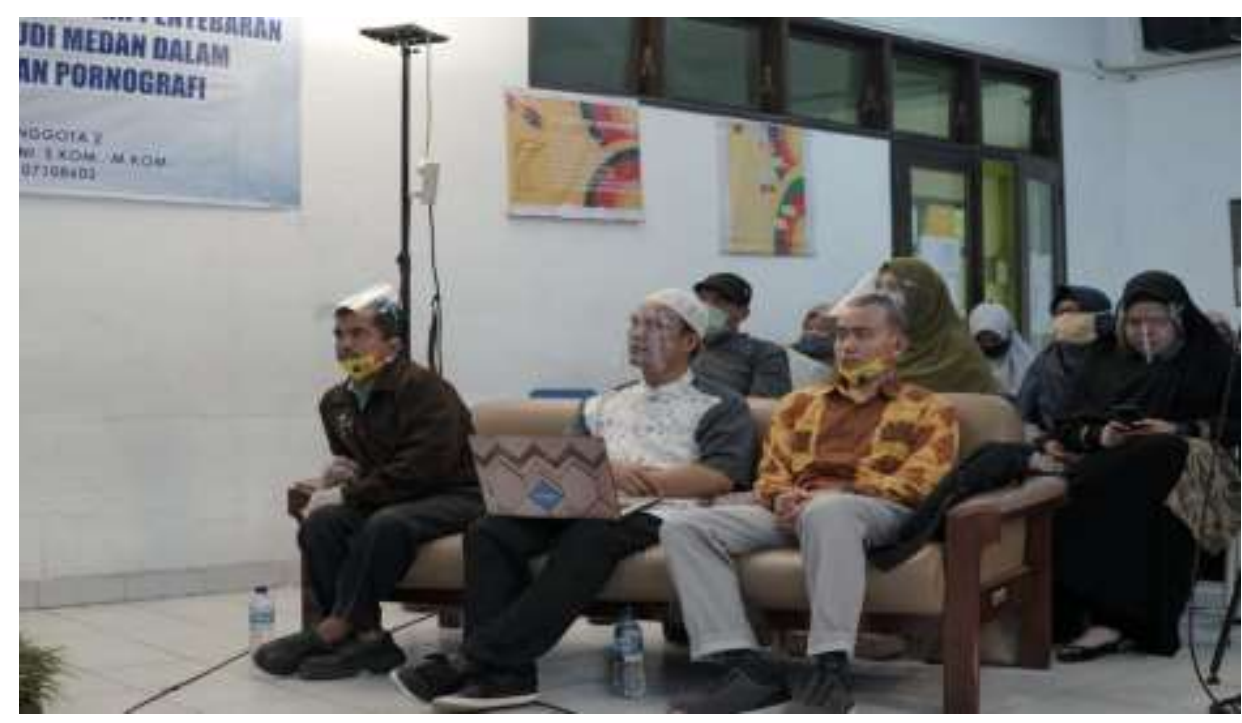

Gambar 2. Foto Suasana Kegiatan Webinar

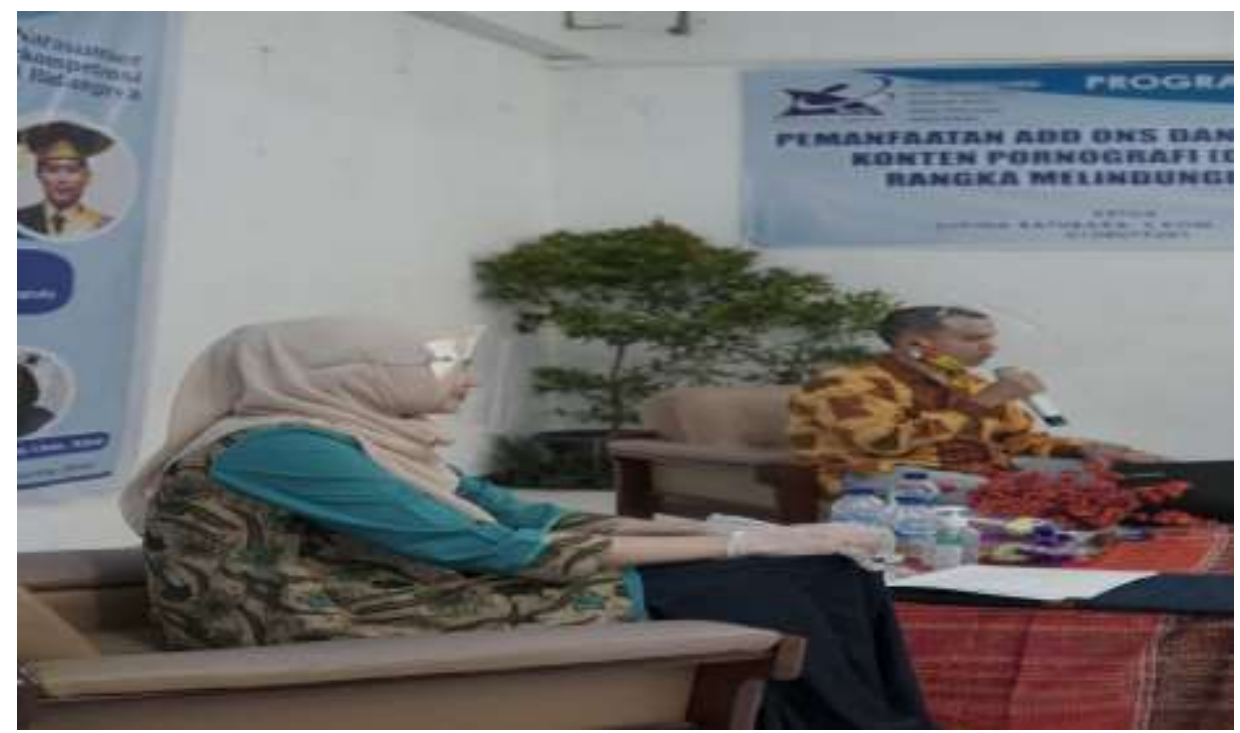

Gambar 3. Penyampaian materi Proteksi Pada Browser oleh Tim PKMS

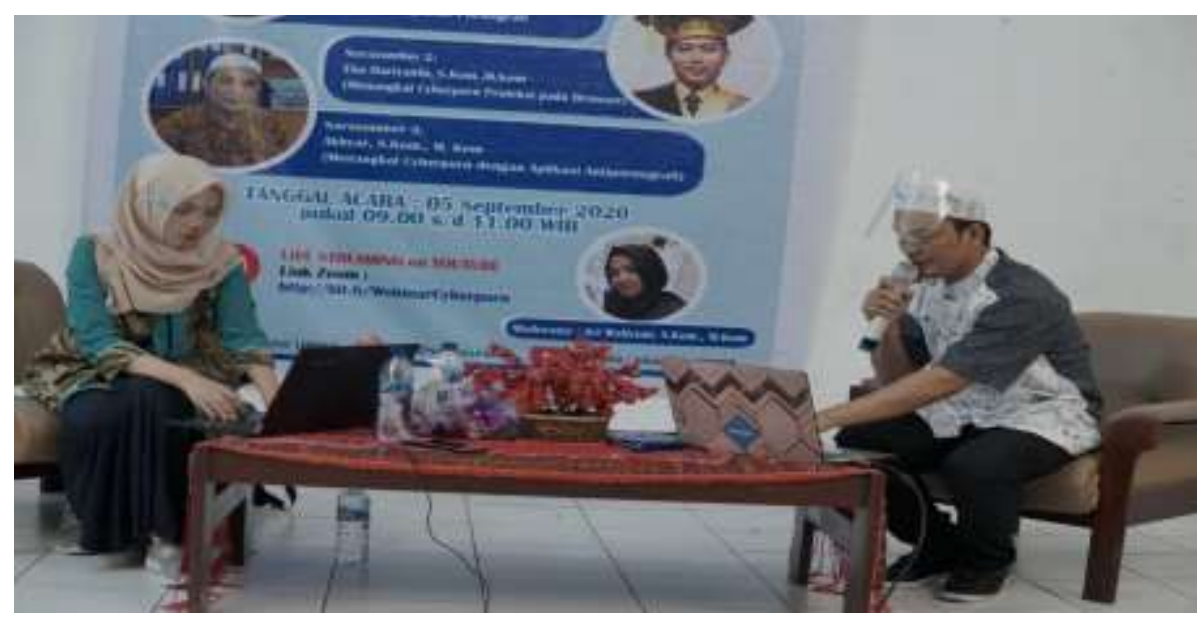

Gambar 4. Penyampaian Materi Aplikasi Antipornografi Net Nanny Oleh Tim PKMS 


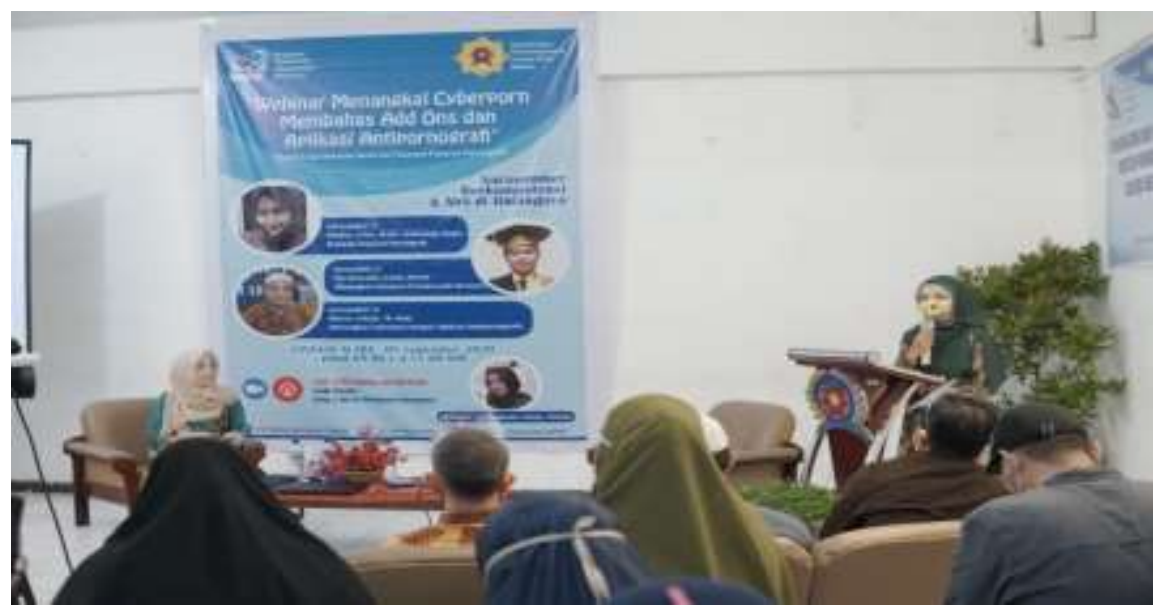

Gambar 5. Penyampaian Materi Lanjutan Proteksi Pada Browser oleh Tim PKMS

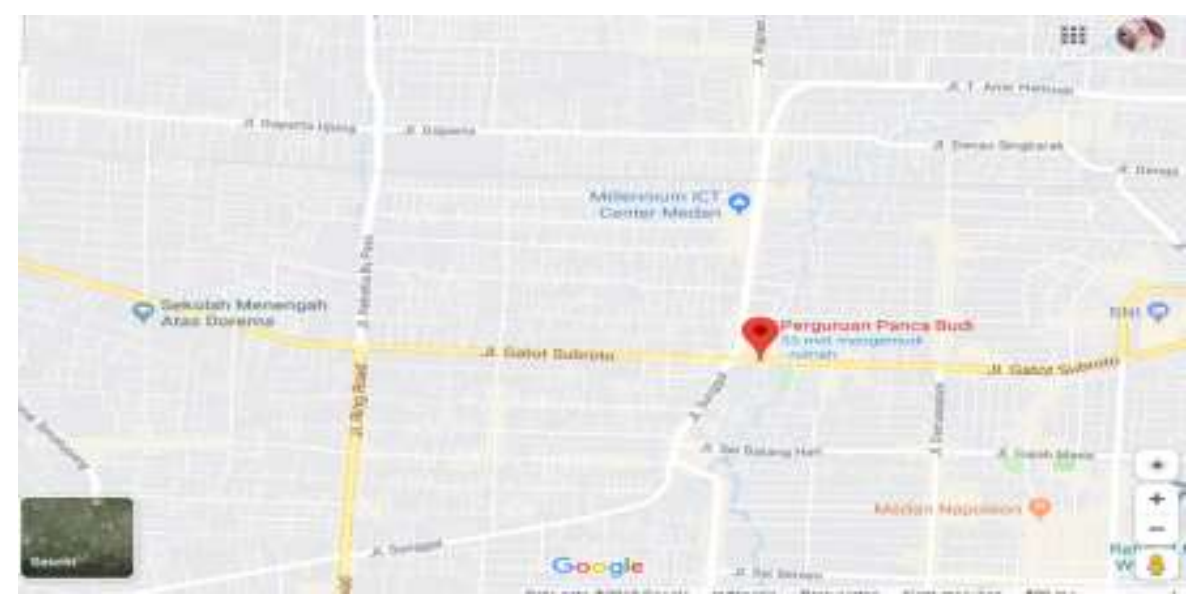

Gambar 6. Lokasi Kegiatan PKMS

\section{Simpulan dan Rekomendasi}

Pelaksanaan Webinar Menangkal Cyberporn Pemanfaatan Add Ons Dan Aplikasi Antipornografi Parental Control Di SMA Panca Budi untuk memblokir konten pornografi pada anak dan melindungi generasi muda dari dampak paparan pornografi. Peserta mampu memahami manfaat pengawasan penggunaan internet bagi keluarga, memahami dampak negative terpapar pornografi, memahami bahaya internet dengan tanpa pengawasan, mampu memanfaatkan add ons dan menggunakan aplikasi antipornografi net nanny yang berfungsi sebagai parental control.Webinar ini diharapkan dapat membantu masyrakat dalam memblokir cyberporn.

\section{Acknowledgements}

Kesuskesan Tim PKMS dalam melaksanakan Webinar Menangkal Cyberporn Pemanfaatan Add Ons Dan Aplikasi Antipornografi Parental Control Di SMA Panca Budi tak luput dari peran serta Kementrian Riset dan Teknologi Badan Riset dan Inovasi Nasional Republik Indonesia yang telah mendanai Program Kemitraan 
Masyarakat yang berjudul "Pemanfaatan Add Ons dan Aplikasi Antipornografi Untuk Memblokir Konten Pornografi (Cyberporn) di SMA Panca Swasta Panca Budi Medan Dalam Rangka Melindungi Generasi Muda Dari Dampak Paparan Pornografi, Universitas Pembangunan Panca Budi dan LPPM UNPAB yang telah memberikan dukungan dengan memfasiltasi segala hal yang dibutuhkan oleh Tim PKMS dalam melaksanakan kegiatan, administrasi dan lain sebagainya . Kepala Sekolah SMA Swasta Panca Budi Bapak Sugangsar, S.Pd yang sudah bersedia untuk bermitra, Kepada Oarang Tua Wali murid, Wali Kelas dan Staff SMA Swasta Panca Budi yang telah turut seerta menikuti runtunan acara sampai selesai, kepada Vendor yang telah berpartisipasi dan kepada mahasiswa dan mahasiswi yang telah membantu demi kelancaran kegiatan.

\section{Daftar Pustaka}

Anwar, M. T. (2018). Analisis Pola Persebaran Pornografi pada Media Sosial dengan Social Network Analysis. Jurnal Buana Informatika, 9(1), 43-52. https://doi.org/10.24002/jbi.v9i1.1667

Bunga, D. (2011). Penanggulangan Pornografi dalam Mewujudkan Manusia Pancasila [Countermeasures Pornography in Realizing Pancasila Humans]. Jurnal Konstitusi, 8(4), 453-478.

Diana, D. I. (2018). Studi Kasus Kecanduan Pornografi Pada Remaja. Motiva Jurnal Psikologi, 1(2), 56. https://doi.org/10.31293/mv.v1i2.3688

Hariyani, M., Mudjiran, M., \& Syukur, Y. (2012). Dampak Pornografi Terhadap Perilaku Siswa dan Upaya Guru Pembimbing untuk Mengatasinya. Konselor, 1(2), 1-8. https:// doi.org/10.24036/0201212696-0-00

Hariyanto, E., \& Wahyuni, S. (2020). Sosialisasi Dan Pelatihan Penggunaan Internet Sehat Bagi Anggota Badan Usaha Milik Desa (Bumdes) Mozaik Desa Pematang Serai. Jurnal Abdimas BSI: Jurnal Pengabdian Kepada Masyarakat, 3(2), 253-259. https://doi.org/10.31294/jabdimas.v3i2.8449

Hasanah, U., Vokasional, P., Keluarga, K., \& Jakarta, U. N. (2017). Workshop Parental Control Berbasis Android Untuk Mencegah Akses Konten Pornografi Pada Anak Usia. 14(02).

Hodson, B., Mendy, B., \& Födi, L. E. (2013). Visual. Working with Multimodality: Rethinking Literacy in a Digital Age, 44-59. https://doi.org/10.4324/9780203071953

Maisyaa, I. B., \& Masitoh, S. (2019). Derajat Keterpaparan Konten Pornografi Pada Siswa Smp Dan Sma Di Dki Jakarta Dan Banten Indonesia. Jurnal Kesehatan Reproduksi, 10(2), 117-126. https:/ / doi.org/10.22435/kespro.v10i2.2463.117-126 
Owens, E. W., Behun, R. J., Manning, J. C., \& Reid, R. C. (2012). The impact of internet pornography on adolescents: A review of the research. Sexual Addiction E Compulsivity, 19(1-2), 99-122. https://doi.org/10.1080/10720162.2012.660431

Rachmaniar, R., Prihandini, P., \& Janitra, P. A. (2018). Perilaku Penggunaan Smartphone dan Akses Pornografi di Kalangan Remaja Perempuan. Jurnal Komunikasi Global, 7(1), 1-11. https:// doi.org/10.24815/jkg.v7i1.10890

Santoso, T. (2017). Pornografi dan Hukum Pidana. Jurnal Hukum \& Pembangunan, 26(6), 513. https://doi.org/10.21143/jhp.vol26.no6.1080

Sinković, M., Štulhofer, A., \& Božić, J. (2013). Revisiting the Association between Pornography Use and Risky Sexual Behaviors: The Role of Early Exposure to Pornography and Sexual Sensation Seeking. The Journal of Sex Research, 50(7), 633-641. https://doi.org/10.1080/00224499.2012.681403

Sudrajat, A. (2010). Pornografi dalam Lintasan Sejarah [Pornography In Historical Trajectory]. Humanika, Vol. 6(No. 1), 1-14.

Utomo. (2018). Perkembangan Mental Remajadi Sekolah. 6(1), 167-187.

Yati, M., \& Aini, K. (2018). Studi Kasus: Dampak Tayangan Pornografi Terhadap Perubahan Psikososial Remaja. Jurnal Ilmu Dan Teknologi Kesehatan, 9(2), 64-71. https://doi.org/10.33666/jitk.v9i2.189 